\title{
SISTEM PAKAR DIAGNOSA PERMASALAHAN PADA PESAWAT CESSNA GRAND CARAVAN 208B MENGGUNAKAN METODE BACKWARD CHAINING
}

\author{
Rianto \\ Magister Teknik Informatika \\ Universitas Atma Jaya Yogyakarta \\ Jalan Babarsari No.43, Yogyakarta \\ rian_r $\mathbf{r}(a$ ymail.com
}

\begin{abstract}
Success of an aircraft mechanic is to find a problem and solve it. Analysis of the problems in the Cessna Grand Caravan 208B needed someone expert in the field of aircraft mechanics. In this research expert system is used to provide easily diagnose problems with the Cessna Grand Caravan $208 B$ by adopting the knowledge possessed from a professional mechanic, then take it into the software, that will be called by the expert system. Backward Chaining method used to obtain the results as expected by a professional mechanic. Search tecniques used to supplement the backward chaining method is a Best-First Search technique. Best-First Search Techniques is a search technique to that used to perform a search based on the knowledge gained to conduct a proper solution where it is located.
\end{abstract}

Keywords: Expert system, Backward chaining, Best-first search, Cessna

\begin{abstract}
Abstrak
Sukses dari seorang mekanik pesawat adalah menemukan masalah dan mengatasinya. Mendiagnosa permasalahan pada pesawat Cessna Grand Caravan 208B dibutuhkan seseorang ahli di bidang mekanik pesawat. Pada penelitan ini sistem pakar digunakan untuk memberikan kemudahan dalam mendiagnosa permasalahan pada pesawat Cessna Grand Caravan 208B dengan mengadopsi pengetahuan yang dimiliki oleh seorang mekanik profesional, kemudian memasukkannya ke dalam perangkat lunak yang nantinya disebut dengan sistem pakar. Metode Backward Chaining digunakan untuk mendapatkan hasil seperti yang di harapkan oleh seorang mekanik profesional. Tenik pencarian yang digunakan untuk melengkapi metode backward chaining tersebut yaitu teknik Best-First Search. Teknik Best-First Search merupakan salah satu teknik pencarian dengan yang digunakan dengan melakukan pencarian berdasarkan pengetahuan yang diperoleh untuk melakukan pencarian tepat di mana solusi itu berada.
\end{abstract}

Kata kunci: Sistem pakar, Backward chaining, Best-first search, Cessna

\section{Pendahuluan}

Indonesia merupakan negara kepulauan, transportasi adalah hal yang mutlak untuk menjadikan sebuah negara lebih berkembang. Kebutuhan transportasi yang lebih cepat sangat diperlukan, transportasi udara merupakan salah satu alternatif yang paling cocok. Penerbangan perintis telah banyak di Indonesia dengan menggunakan pesawat-pesawat kecil bermesin tunggal dengan menggunakan baling-baling. Salah satunya adalah Cessna Grand Caravan 208B, jenis pesawat ini telah banyak digunakan oleh Susi Airlines untuk menjangkau wilayah-wilayah di Indonesia untuk bandara-bandara yang tidak mempunyai landasan yang panjang. 
Kebutuhan maintenance dibutuhkan dalam melakukan perawatan pesawat secara berkala, akan tetapi perawatan membutuhkan biaya yang tidak murah. Selain kemampuan mekanik untuk mengidentifikasi gejala-gejala kerusakan yang terdapat pada sebuah pesawat, dibutuhkan pula peralatan yang mendukung untuk proses operasional.

Sistem Pakar menjadi salah satu alternatif yang bisa digunakan untuk membantu mekanik dalam mendiagnosa kerusakan-kerusakan yang terjadi pada pesawat. Selain metode yang digunakan, penyusunan sistem pakar harus terdapat tiga buah modul utama yaitu penerimaan pengetahuan, konsultasi, dan penjelasan. Pada penelitian ini sistem pakar digunakan untuk mendiagnosa permasalahan pada pesawat Cessna Grand Caravan 208B. Aplikasi yang dibangun menggunakan bahasa pemograman PHP, Javascript, dan database MySql.

\section{Metode Penelitian}

Pada penelitian ini bersifat deskriptif. Berdasarkan data sumber yang diperoleh pada penelitan ini, data dibagi menjadi dua yaitu data primer yang berasal dari pengambilan data di lapangan secara langsung pada maskapai penerbangan Susi Airlines dan data sekunder yang berupa kumpulan data dari literatur-literatur yang berhubungan dengan metode backward chaining dan permasalahan-permasalahan yang terjadi pada pesawat Cessna Grand Caravan 208B.

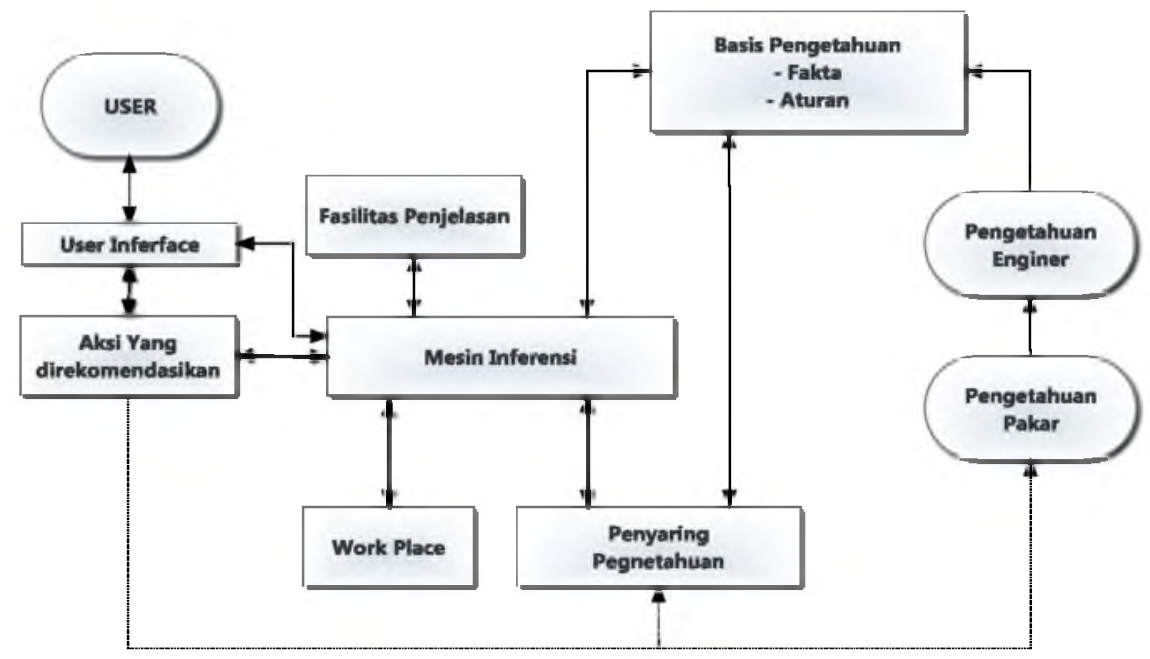

Gambar 1. Struktur Sistem Pakar (Turban, 2005)

\subsection{Backward Chaining}

Dalam sistem pakar terdapat inference engine yang digunakan untuk menemukan obyek yang sesuai dengan informasi yang diperoleh. Dasar yang digunakan untuk membentuk inference engine salah satunya dengan metode forward chaining, dan rule value. Dalam hal ini Backward Chaining merupakan sebuah teknik penalaran yang biasa digunakan dalam sebuah sistem pakar. Penalaran yang digunakan dalam backward chaining yaitu dengan cara melakukan pelacakan kebelakang, dalam hal ini diambil dari kesimpulan yang paling belakang, mencari hipotesa untuk mendapatkan fakta yang dapat mendukung. Backward chaining disebut juga dengan Object-Driven/Goal-Driven, dimulai dengan dengan sebuah obyek kemudian meminta informasi untuk meyakinkan ataupun mengabaikan informasi tersebut. 


\subsection{Teknik Best-First Search}

Teknik Best-first Search merupakan salah teknik yang digunakan untuk melengkapi metode backward chaining. Teknik best first search merupakan teknik pencarian dengan menggunakan pengetahuan suatu masalah, dengan pengetahuan tersebut akan diperoleh arah node-node tempat di mana solusi itu akan ditemukan. Pendekatan yang digunakan pada teknik ini dengan melakukan pencarian solusi terbaik dengan berdasarkan dari pengetahuan yang dimiliki. Dengan menggunakan teknik ini proses pencarian dapat ditentukan, sehingga didapatkan proses terbaik untuk mendapatkan solusi.

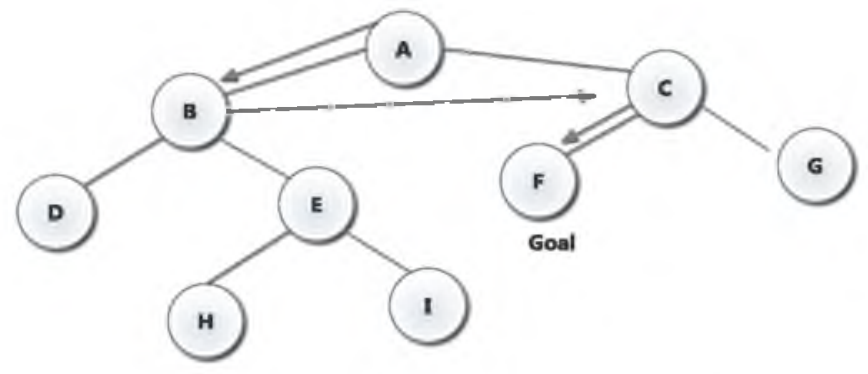

Gambar 2. Teknik Best First Search

\section{Analisa Data}

\subsection{Diagram alur proses}

Diagram alur proses menggambarkan jalannya proses perangkat lunak yang akan dijalankan. Diagram alur proses ini dapat dilihat pada gambar 3.

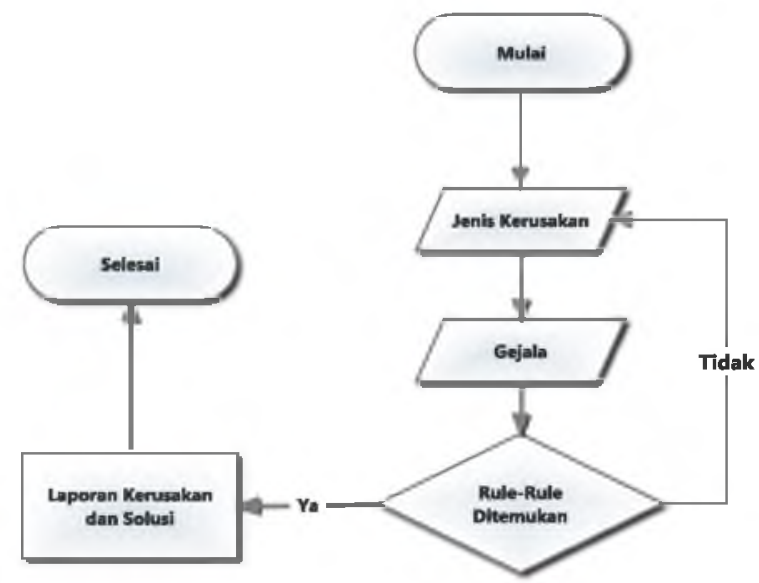

Gambar 3. Diagram Alur proses

\subsection{Data Flow Diagram}

Diagram konteks penelitian

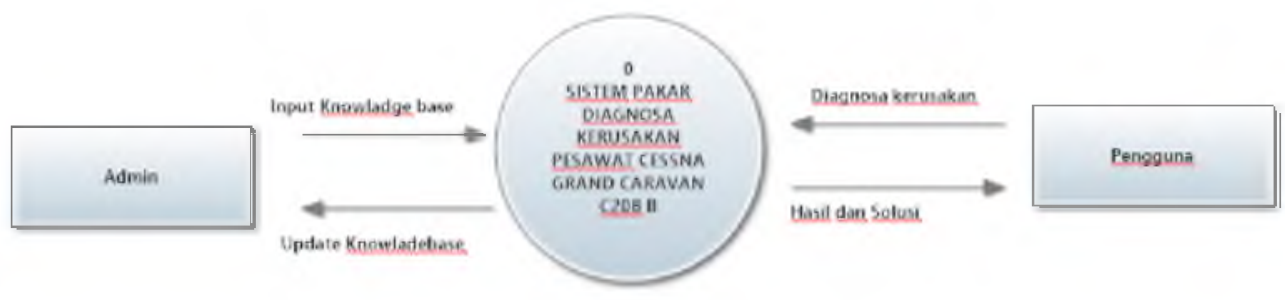

Gambar 3. Diagram konteks 
Data Flow Diagram Level 1

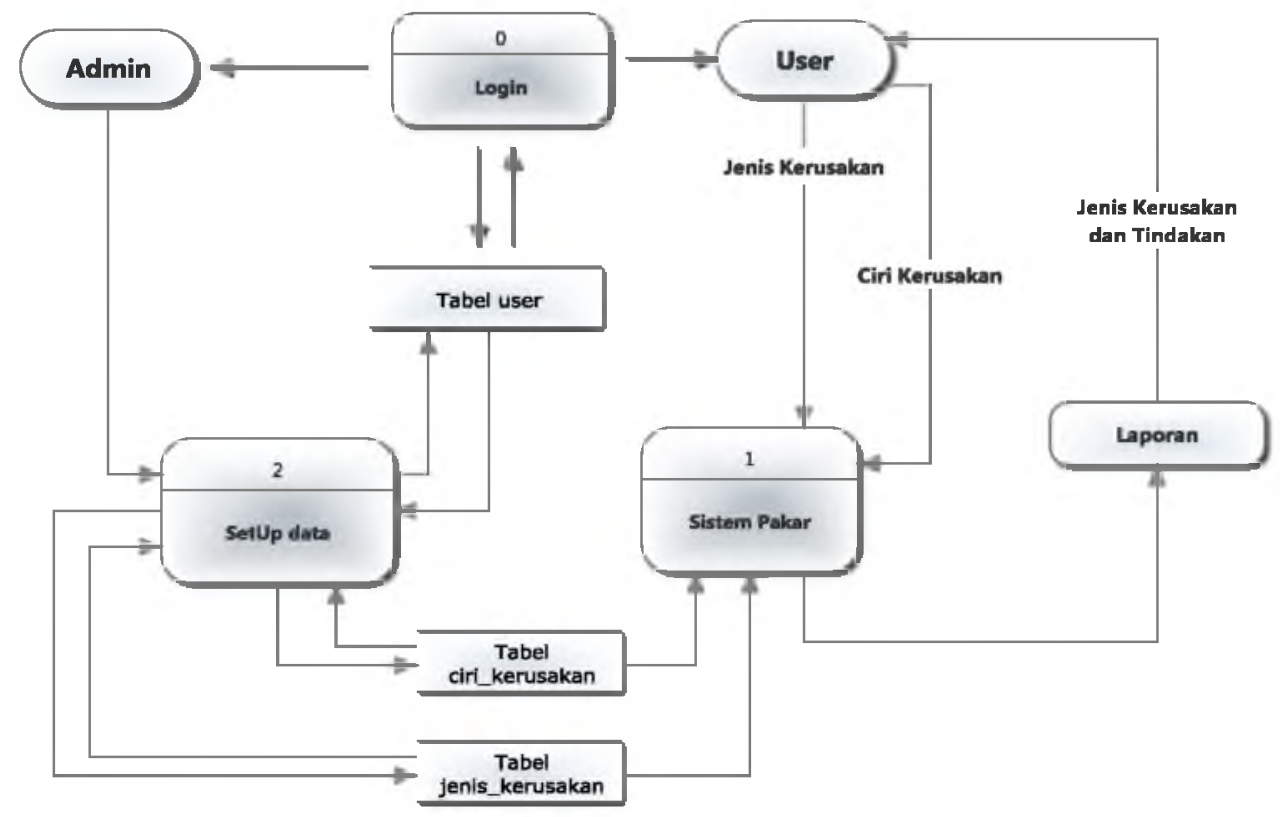

Gambar 4. DFD Level 1

\subsection{Perancangan Database}

Tabel 1. Tabel User

\begin{tabular}{lccc}
\hline Field & Type & Size & Key \\
\hline Id_user & Int & 9 & PK \\
Nama_user & varchar & 100 & \\
Username & Varchar & 100 & \\
Password & Varchar & 50 & \\
Email & Varchar & 50 & \\
\hline
\end{tabular}

Tabel 2. Tabel jenis_kerusakan

\begin{tabular}{lccc}
\hline Field & Type & Size & Key \\
\hline $\begin{array}{l}\text { Id_kerusakan } \\
\text { Jenis kerusakan }\end{array}$ & $\begin{array}{c}\text { Int } \\
\text { text }\end{array}$ & 9 & PK \\
& & \\
\multicolumn{4}{c}{ Tabe1 3. Tabel ciri kerusakan } \\
\hline Field & Type & Size & Key \\
\hline Id_ciri & int & 9 & PK \\
Id_kerusakan & Int & 9 & FK \\
Cirinya & text & & \\
\hline
\end{tabular}

Tabel 4. Tabel kerusakan

\begin{tabular}{lccc}
\hline Field & Type & Size & Key \\
\hline kode_kerusakan & int & 9 & PK \\
kode_jenis_rusak & Int & 9 & FK \\
Solusi & text & & \\
kode ciri kerusakan & text & & \\
\hline
\end{tabular}




\subsection{Basis Pengetahuan}

Basis pengetahuan sering disebut dengan Rule Based Reasoning, tabel basis pengetahuan digunakan sebagai dasar pengetahuan dari sebuah sistem pakar. Tabel basis pengetahuan dapat dilihat pada tabel 5 yang ditampilkan hanya beberapa rule.

Tabel 5. Basis Pengetahuan

\begin{tabular}{|c|l|}
\hline 1 & $\begin{array}{l}\text { IF saat landing terjadi kebocoran ban karena hentakan di runway AND landing } \\
\text { low performance AND take off low performance THEN terjadi goresan pada } \\
\text { ban penanganan ban harus diganti }\end{array}$ \\
\hline 2 & $\begin{array}{l}\text { IF Pilot tidak bisa melihat posisi pesawat saat terbang AND Take off landing } \\
\text { eror AND pesawat hanya bisa jelajah THEN kerusakan pada Artificial Horizon } \\
\text { penanganan harus ganti Artificial Horizon }\end{array}$ \\
\hline 3 & $\begin{array}{l}\text { IF indicator penunjuk arah pada pesawat tidak sesuai AND pilot sulit } \\
\text { komunikasi terhadap ATC AND pilot kesulitan dalam menetukan posisi } \\
\text { pesawat THEN terjadi kerusakan pada Navigator Instrument penangangan Cek } \\
\text { Magnetic Compas }\end{array}$ \\
\hline 4 & $\begin{array}{l}\text { IF Frekuensi tidak jelas dalam penanggapan suara AND ATC tidak bisa } \\
\text { komunikasi, AND pilot sulit dalam mengambil arah atau posisi landing di } \\
\text { bandara THEN terjadi kerusakan pada System Navigator, penanganan cek } \\
\text { Radio Magentic Indicator }\end{array}$ \\
\hline 5 & $\begin{array}{l}\text { IF arah tujuan pesawat tidak bisa terbaca dengan jelas AND pilot tidak bisa } \\
\text { menentukan angle of attack AND pesawat tidak bisa terkontrol dengan baik } \\
\text { dalam menentukan ketinggian pesawat THEN terjadi kerusakan system } \\
\text { Navigator intrument, penanganan cek pada Course Indicator }\end{array}$ \\
\hline 6 & $\begin{array}{l}\text { IF saat pitch pesawat tidak bisa akselerasi AND kecepatan pesawat berkurang } \\
\text { AND peswat tidak bisa take off dengan sempurna AND pesawat mengalami } \\
\text { kesulitan dalam melakukan terbang horizontal THEN terjadi kerusakan pada G } \\
\text { Meter, penanganan cek Accelerometer }\end{array}$ \\
\hline 7 & $\begin{array}{l}\text { IF tekanan udara tidak bisa dikurangi AND kadar tidak bisa menyesuaikan } \\
\text { dengan daerah AND panas di cabin AND over heating di engine AND power } \\
\text { engine low THEN Terjadi kerusakan pada Suction gauge, penanganan cek } \\
\text { instrument pada Suction gauge }\end{array}$ \\
\hline 8 & $\begin{array}{l}\text { IF saat belok di runway pesawat fail AND landing gear sulit di kendalikan pilot } \\
\text { AND hidrolik mengalami kebocoran oli THEN terjadi kerusakan pada turn dan } \\
\text { bank indcator, penanganan cek turn dan bank indicator }\end{array}$ \\
\hline
\end{tabular}

\section{Hasil dan Pembahasan}

\subsection{Implementasi Sistem}

Hasil implementasi pada diagnosa kerusakan pesawat Cessna Grand Caravan 208B berbasis web yang menggunakan metode backward chaining. Aplikasi ini dibangun berbasis web supaya dapat memberi kemudahan bagi penggunanya untuk menggunakan aplikasi, karena dapat diakses di mana saja selama koneksi internet tersedia. 
Riyanto

\subsection{Tampilan Layar Awal}

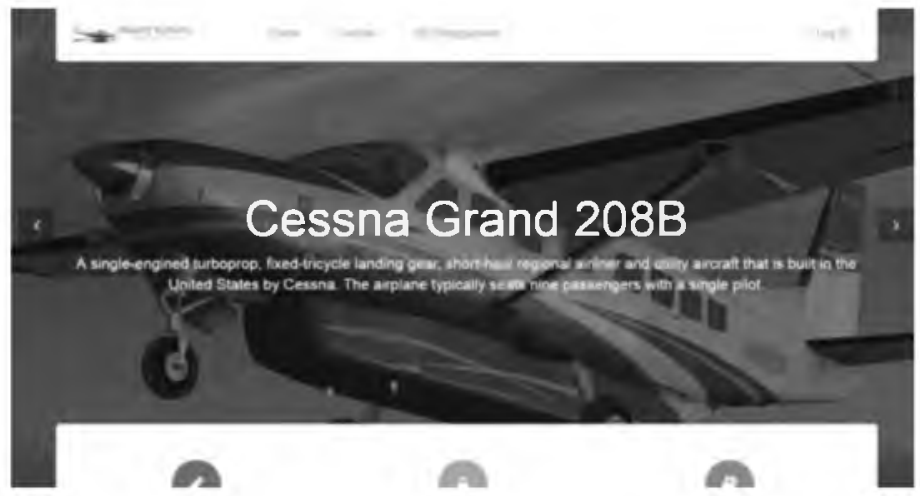

Gambar 5. Tampilan awal sebelum login

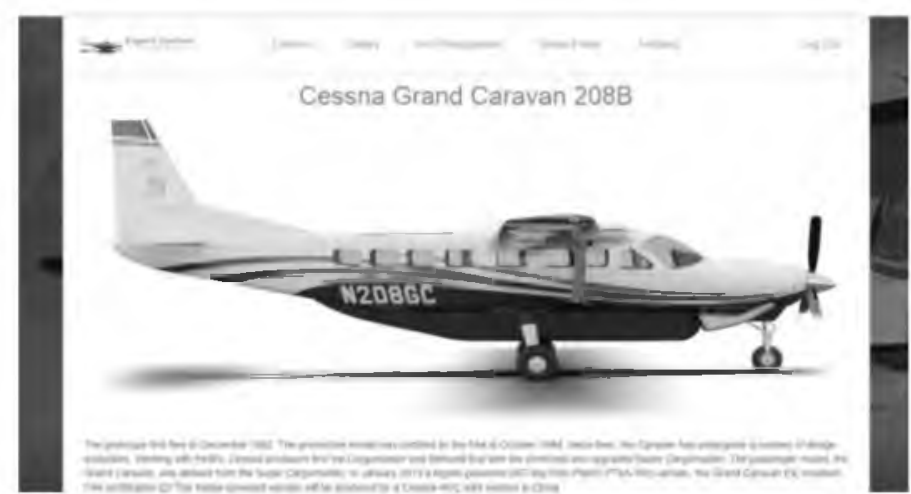

Gambar 6. Tampilan awal setelah login

Pada gambar 5 dan gambar 6 menunjukkan saat aplikasi dijalankan, di mana dapat dilihat pada gambar 5 adalah aplikasi tampil saat pengguna belum login, dan gambar 6 adalah tampilan aplikasi setelah pengguna login.

\subsection{Pendaftaran dan Login}

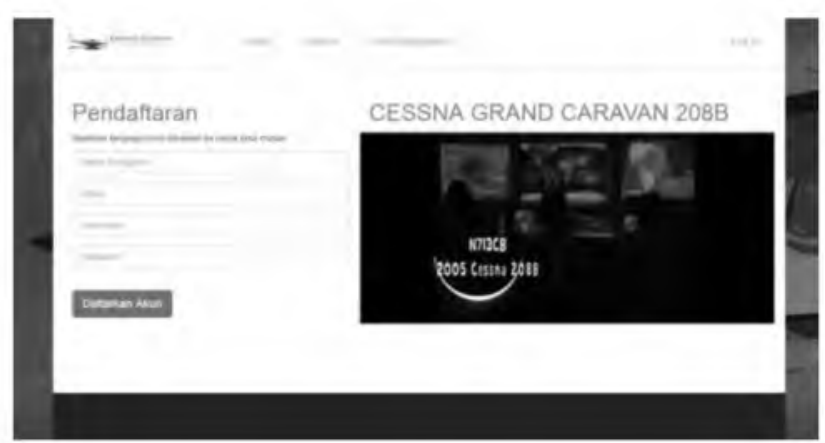

Gambar 7. Form pendaftaran 


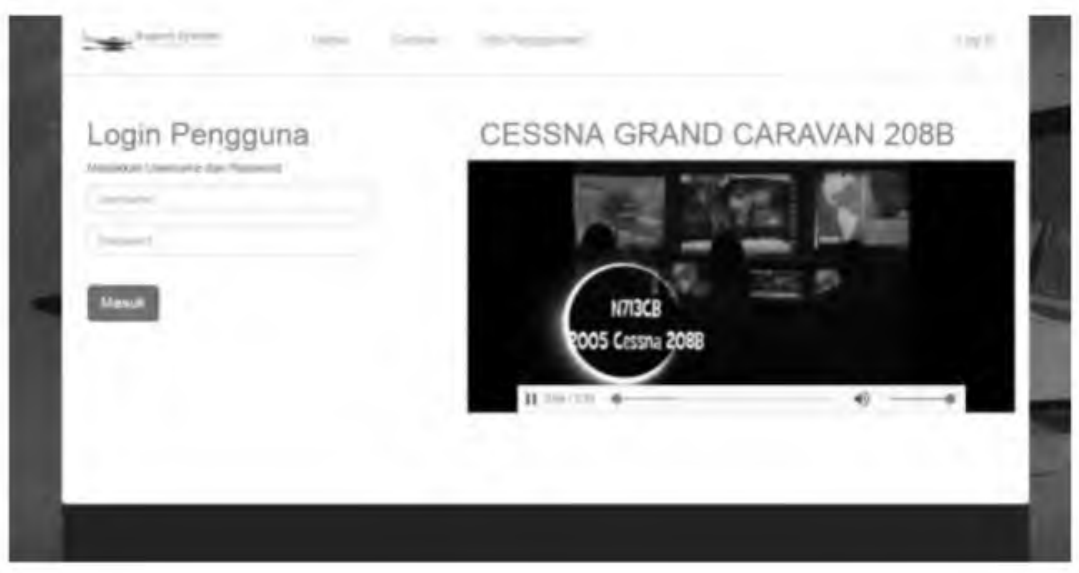

Gambar 8. Form Login

Sebelum menggunakan aplikasi sistem pakar, pengguna diharuskan login terlebih dahulu, apabila belum mempunyai akun untuk login, maka harus mendaftarkan terlebih dahulu, setelah itu baru pengguna bisa menggunakan aplikasi sistem pakar.

\subsection{Penggunaan Sistem Pakar}

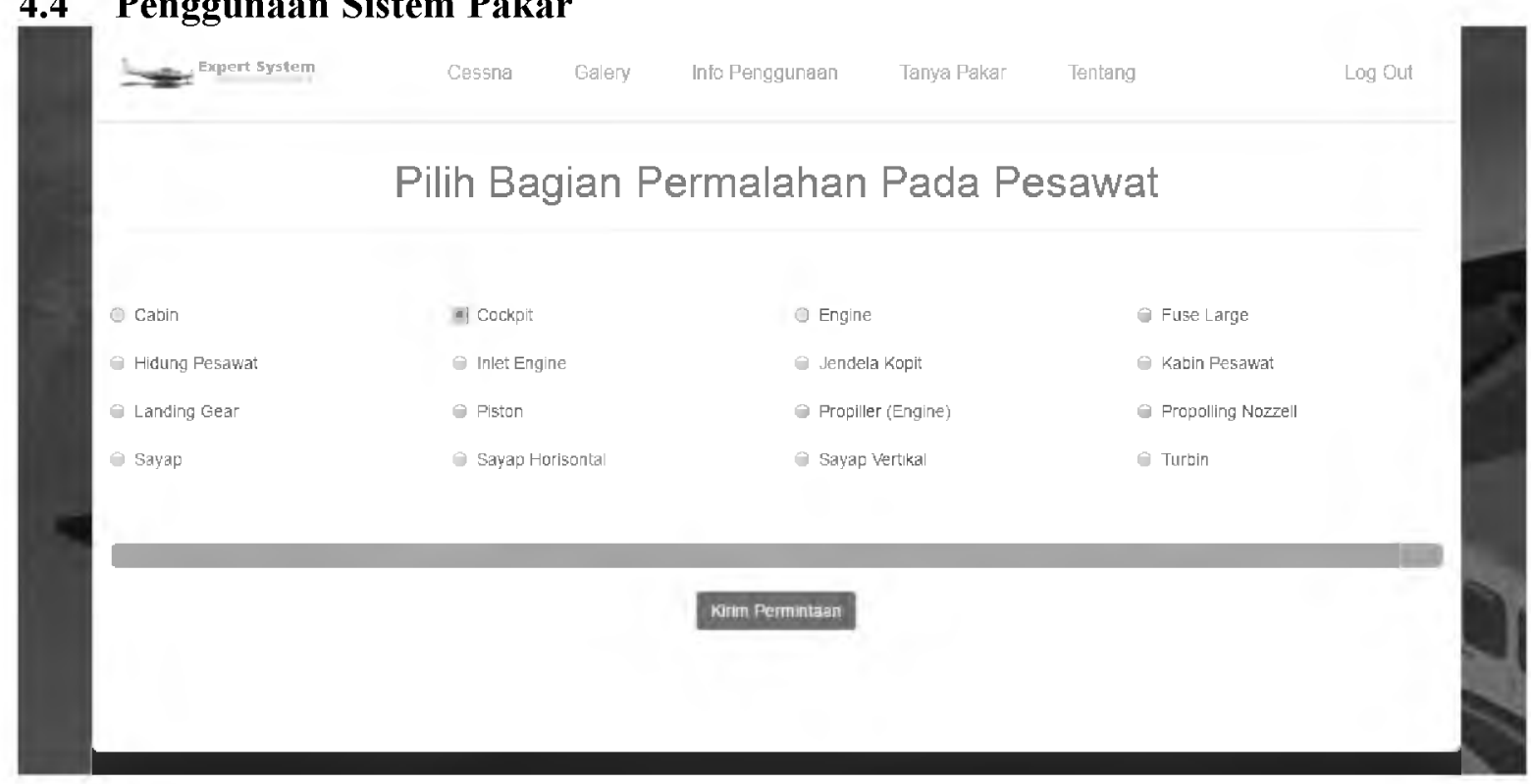

Gambar 9. Pemilihan bagian permasalahan pesawat

Pada bagian ini pengguna diarahkan untuk memilih permasalahan yang terjadi pada pesawat, dalam hal ini metode backward chaining diterapkan. Dalam menu akan nampak daftar-daftar kerusakan pada bagian pesawat dan harus memilih untuk dapat ke proses berikutnya. 


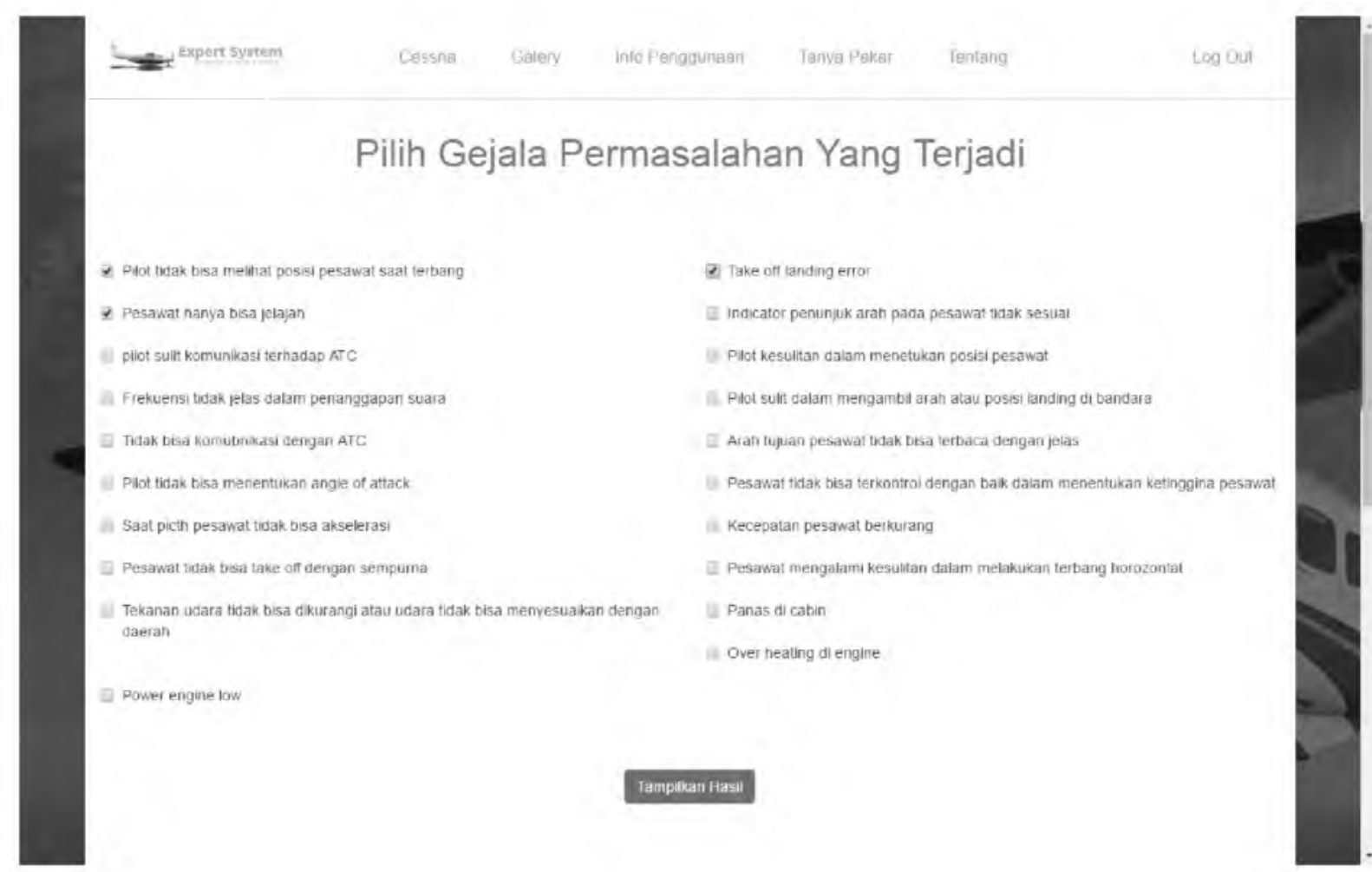

Gambar 10. Pemilihan gejala-gejala dari jenis kerusakan yang dipilih

Pada gambar 10 adalah gejala-gejala atau ciri-ciri yang terjadi pada permasalahan di Cockpit pesawat, untuk setiap bagian kerusakan mempunyai ciri-ciri yang berbeda-beda sehingga tampilan gejala akan selalu berbeda-beda tergantung dari pemilihan bagian permasalahan pada pesawat. Pada tahap ini teknik best first-search akan digunakan untuk mencari atau mendapatkan hasil yang diinginkan.

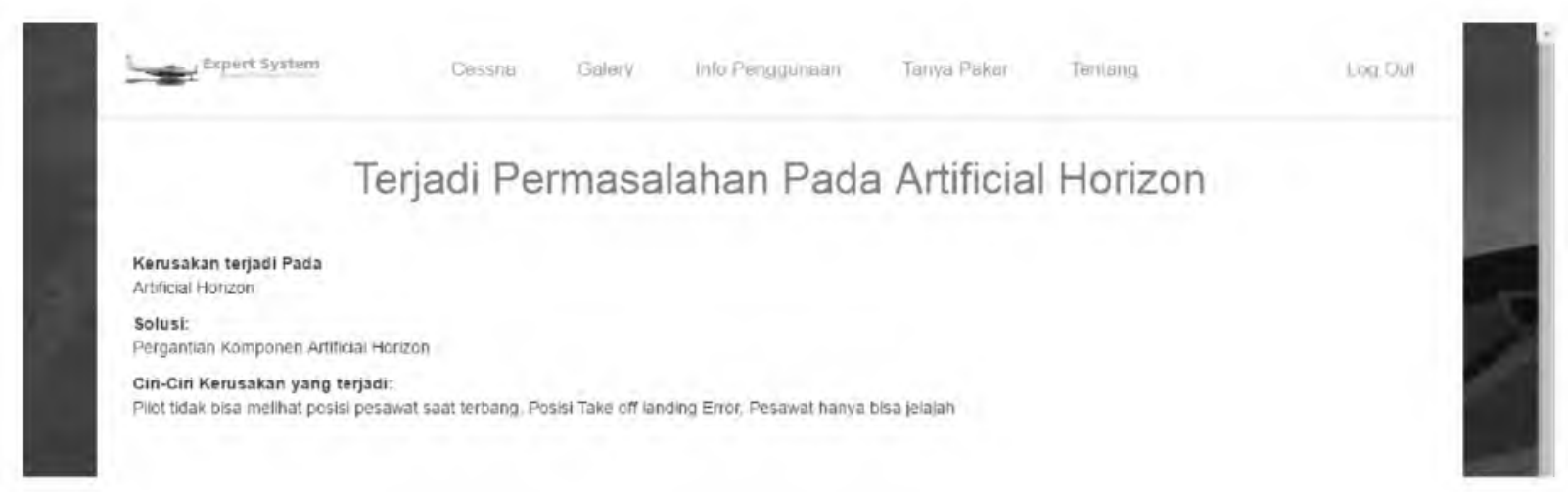

Gambar 11. Hasil keluaran dari sistem pakar yang diperoleh

Pada gambar 11 adalah hasil akhir dari penggunaan sistem pakar, di mana didapatkan hasil permasalahan terjadi pada Artificial Horizon yang diperoleh dari ciri-ciri pilot tidak bisa melihat posisi pesawat saat terbang, posisi Take off landing Error, dan pesawat hanya bisa jelajah. 


\subsection{Komponen dan Kelebihan Sistem pakar}

Komponen-komponen menu yang terdapat dalam aplikasi ini adalah sebagai berikut.

a. Pendaftaran dan Login, pada halaman ini pengguna baru harus membuat akun terlebih dahulu supaya bisa masuk menggunakan aplikasi sistem pakar.

b. Info Penggunaan, pada halaman ini pengguna dapat mengetahui cara menggunakan aplikasi sistem pakar ini.

c. Halaman admin, pada halaman ini admin dapat melakukan pengelolaan pada tabel knowledge base di dalamnya, yang menjadi pusat pengetahuan dari sistem pakar ini.

d. Aplikasi ini mendeteksi jenis kerusakan dengan menentukan dahulu pokok kerusakan yang terjadi kemudian memberikan ciri-ciri kerusakan dan mendapatkan hasisl sesuai dengan kerusakan tersebut.

e. Sistem ini akan melakukan penelusuran terhadap gejala-gejala yang dipilih oleh pengguna untuk mendapatkan jenis kerusakan dan solusi dari kerusakan tersebut.

\section{Kesimpulan}

Aplikasi sistem pakar ini digunakan untuk mendiagnosa permasalahan yang terjadi pada pesawat Cessna Grand Caravan 208B menggunakan metode Backward Chaining dengan teknik penelusuran Best-First Search untuk mendapatkan hasil yang terbaik. Sistem ini dibangun dengan berbasis web, untuk setiap pengguna yang ingin menggunakan aplikasi ini harus membuat sebuah akun untuk login. Sistem pakar ini dibangun berbasis web, dengan harapan supaya dapat diakses oleh siapa saja khususnya mahasiswa penerbangan yang ingin belajar tentang maintenance pesawat Cessna Grand Caravan 208B dan mekanik-mekanik muda yang masih dalam proses belajar.

\section{Daftar Pustaka}

Al, D., Perhinschi, M. G., Moncayo, H., \& Perez, A. (2015). Control Engineering Practice A dendritic cell mechanism for detection, identi fi cation, and evaluation of aircraft failures. Control Engineering Practice, 41, 134-148.

Fitriastuti, F \& Ekowati, L.S. (2009). Aplikasi sistem pakar berbasis web untuk mendeteksi kerusakan perangkat keras komputer dengan metode, 95-106.

Hui, Y., Qin, Y., \& Shigeyuki, M. (1996). An Artificial Intelligence System Of Trouble Diagnosis tr $^{\circ}$ " blelayer, 8352(96), 797-801.

Nugraha, D. W. (2014). Sistem Pakar Untuk Mendiagnosa Kerusakan Perangkat Televisi Menggunakan Metode Backward Chaining, 10(2), 113-126.

Soleh, I., \& Tiruan, K. (2010). Sistem Pakar Untuk Identifikasi Bunga Yang Bermanfaat Bagi Kesehatan Berbasis Mobile..

Suyanto. 2014. Artificial Intelligence: Searching, Reasoning, Planning, dan Learning, Revisi Kedua,Penerbit Informatika, Bandung.

Tomsovic, K., \& Liu, C. (1993). Bounding the computation time of forward-chaining rulebased systems, 0, 317-334. 
Riyanto

Tout, K. R., \& Evans, D. J. (1992). Practical aspects and experiences Parallel forward chaining technique with dynamic scheduling , for rule-based expert systems, 18, 913930.

Turban E., Aroson J.E, Liang T.P.,(2005). Decision Support System and Intelligent System (Sistem Pendukung keputusan dan Sistem Cerdas), Edisi 7, Jilid 2, CV. Andi Offset, Yogyakarta. 